DOI $10.14746 / \mathrm{ssp} .2015 .1 .5$

Beata PAJĄK-PATKOWSKA

Uniwersytet im. Adama Mickiewicza w Poznaniu

\title{
Przesłanki stabilności demokracji - legitymizacja systemu na poziomie indywidualnym
}

Streszczenie: Celem artykułu jest przedstawienie procesu legitymizowania systemu demokratycznego na poziomie obywateli - ich postaw i zachowań, w kontekście przemian, jakie zachodzą w bardziej zaawansowanych w procesie demokratyzacji niż Polska, krajów. Punktem wyjścia jest teoria J. J. Linza, wskazująca na zależności pomiędzy stabilnością systemu a legitymizacją. Dalej omawiane są liczne badania dotyczące przejawów legitymizacji systemu na poziomie indywidualnym w Polsce oraz krajach Zachodniej Europy oraz sprawdzana jest hipoteza dotycząca zależności pomiędzy przemianami aktywności politycznej (w tym wzrostem aktywności typu niekonwencjonalnego) a stopniem legitymizacji systemu.

Słowa kluczowe: legitymizacja, aktywność polityczna, demokracja, postawy wobec demokracji, stabilność demokracji

\section{Stabilność a demokracja}

Tak zakłada J. J. Linz, stabilność systemu zależy od trzech elementów - legitymizacji właśnie, sprawności i skuteczności. Legitymizację definiować będziemy jako proces wytwarzania akceptacji dla systemu politycznego i podmiotów władzy. Sprawność to wydajność procesu decyzyjnego, zaś skuteczność to pożądane efekty realizacji podjętych decyzji (Linz, 1998). Jak wskazuje ten autor, kluczowe dla procesu legitymizacji systemu nie sąjednak ani jego sprawność, ani skuteczność, ale siła przekonania ludzi o jego legitymizacji bądź jej braku.

Przechodząc do problemu legitymizacji władzy na poziomie indywidualnym, wskazać można różne jej przejawy. I tak np. wyróżnić można:

- ocenę struktur i zasad systemu,

- zachowania wobec działań elity władzy,

- postawę wobec zamierzeń elity władzy,

- ocenę wypowiedzi programowych elity,

- postawę wobec osób sprawujących władzę, 
- nadzieje łączone z istniejącym porządkiem (Lamentowicz, za: Sokół, 1997, s. 42).

Spójrzmy zatem, jak wygląda legitymizacja demokracji przez obywateli w Polsce, a następnie w krajach bardziej zaawansowanych w procesie demokratyzacji.

\section{Przejawy legitymizacji systemu demokratycznego na poziomie indywidualnym w Polsce}

Jeśli chodzi o pierwszy z wymienionych przejawów legitymizacji systemu w Polsce, czyli ocenę struktur i zasad systemu, to na pierwszy rzut oka, nie wygląda to najgorzej. Według badań CBOS z 2014 r. 68\% badanych uważa, że demokracja ma przewagę nad innymi formami rządów, ale jest to bardziej wybór mniejszego zła (75\% osób zgadza się z twierdzeniem „Demokracja nie jest dobrym ustrojem, ale nie ma lepszego”). Poza tym aż dla 37\% Polaków jest obojętne, czy rządy są demokratyczne czy nie. Zaś 33\% badanych Polaków uważa, że „czasem rządy niedemokratyczne mogą być bardziej pożądane niż demokratyczne”. W tym przypadku nastąpił spadek wskazań w porównaniu do 2010 r. o 10\%. Nawet więc jeśli większość Polaków ceni demokrację jako pewną ideę, to funkcjonowanie demokracji źle ocenia $41 \%$ badanych. Przy czym wskaźnik ten jest obecnie lepszy niż było to rok temu (58\% niezadowolonych) i zdecydowanie lepszy niż 10 lat temu (71\% niezadowolonych) (CBOS, Opinie...; CBOS, Postawy wobec...).

Jeszcze gorzej wygląda sprawa aktywnego zaangażowania w demokrację. Średni poziom frekwencji w wyborach w Polsce to ok. 50\%, a były też takie wybory, gdzie spadała ona poniżej tej granicy ${ }^{1}$. Jak wskazuje w swoich analizach M. Cześnik, Polacy są także bardzo niestabilni, jeśli chodzi o uczestnictwo w wyborach i zmieniają swoje zachowania $\mathrm{z}$ wyborów na wybory (Cześnik, Grzelak, Kotnarowski, 2004) - norma uczestnictwa w wyborach wydaje się bardzo słabo wykształcona. Przejawia się ona głównie na poziomie deklaratywnym - Polacy wstydzą się w badaniach przyznawać do nieuczestniczenia w wyborach, stąd taka duża różnica pomiędzy deklarowanym uczestnictwem a uczestnictwem faktycznym.

1 Tymczasem uznaje się, że w krajach tzw. nowych demokracji może to być zagrożeniem dla stabilności systemu (por. Skarżyńska, 2005). 
Trzeba tu także wskazać, że frekwencja wyborcza w Polsce jest jedną z najniższych w regionie, choć badania pokazują wyraźny trend spadkowy we wszystkich w zasadzie krajach regionu (Kostadiova, 2003; Cześnik, 2008). W tym kontekście dziwić mogą wyniki sondażu CBOS, w którym $80 \%$ badanych wskazało, że głosowanie w wyborach jest obowiązkiem obywatelskim $^{2}$.

Tymczasem aktywność niekonwencjonalna wydaje się wśród Polaków zyskiwać na popularności. Dużym zainteresowaniem cieszyły się protesty przeciw ACTA (zgromadziły one kilkaset tysięcy osób), Polacy uczestniczyli również $\mathrm{w}$ marszach organizowanych przez $\mathrm{PiS}^{3}$.

Polacy nisko oceniają osoby i instytucje sprawujące władzę. Działalność Sejmu źle ocenia 6\%, Senatu - 40\%, rządu - 40\% badanych. Lepiej oceniana jest działalność Prezydenta (73\% dobrych ocen) i władz samorządowych - ok. 60\% dobrych ocen (CBOS, Oceny wybranych...; CBOS, Oceny instytucji...). Poziom zaufania do polityki i polityków jest bardzo niski (Kalinowska, 2009). W 2014 r. zaufanie do partii politycznych deklarowało 17\% badanych (CBOS, Stosunek do...).

Spójrzmy jeszcze, jak wygląda wymiar nazwany poparcie dla zamierzeń władzy. Jeśli wziąć pod uwagę sprawę ACTA oraz ustawę w sprawie podniesienia wieku emerytalnego, to sprzeciw społeczeństwa był bardzo duży. Przeciwko ACTA było 78\% badanych przez CBOS użytkowników Internetu i 54\% nieużywających Internetu. Przeciw podniesieniu wieku emerytalnego mężczyzn było 79\% badanych, kobiet - 86\% (CBOS, Opinia publiczna...; CBOS, Nadal nieprzekonani...).

Ponadto niemal połowa Polaków uważa, że sytuacja w kraju zmierza w złym kierunku, co i tak jest na warunki polskie bardzo dobrym wynikiem, ponieważ zazwyczaj procent zgadzających się z tym stwierdzeniem oscylował wokół 65\% (CBOS, Nastroje...). Wydaje się, patrząc na typologię postaw obywateli wobec systemu W. Lamentowicza, że Polacy w swej większości znaleźliby się w drugiej jej kolumnie, wykazując obojętność, wycofanie, krytycyzm oraz brak nadziei.

2 Wyniki badania przeprowadzonego przez CBOS w dniach 18-24 sierpnia 2011, za: Sondaż CBOS: Wybory obowiazkiem każdego, „Rzeczpospolita”, wydanie internetowe, http://www.rp.pl/artykul/726960.html.

3 Szczegółowy opis przemian w zakresie aktywności politycznej Polaków w okresie pomiędzy 1989 a 2005 oraz postaw młodzieży wobec aktywności politycznej, zob. B. Pająk, Demokracja polska i niemiecka. Tradycja, teraźniejszość, perspektywy, Poznań 2008, rozdz. 2.3. i 3.3 . 
Reakcje spoleczne wobec wladzy politycznej

\begin{tabular}{||l|l|l|l||}
\hline \multicolumn{1}{|c|}{$\begin{array}{c}\text { Przedmiot reakcji } \\
\text { społecznych }\end{array}$} & \multicolumn{3}{|c||}{ Typy reakcji spolecznych } \\
\hline $\begin{array}{l}\text { Ocena struktur i zasad } \\
\text { systemu }\end{array}$ & Akceptacja & $\begin{array}{l}\text { Obojętność lub ukryty } \\
\text { sprzeciw }\end{array}$ & Jawny sprzeciw \\
\hline $\begin{array}{l}\text { Zachowania wobec dzia- } \\
\text { łań elity władzy }\end{array}$ & Poparcie & Wycofanie lub opór & Bunt \\
\hline $\begin{array}{l}\text { Postawa wobec zamie- } \\
\text { rzeń elity }\end{array}$ & Poparcie & Wycofanie lub opór & Bunt \\
\hline $\begin{array}{l}\text { Ocena wypowiedzi pro- } \\
\text { gramowych elity }\end{array}$ & $\begin{array}{l}\text { Wiarygodność } \\
\text { i zaufanie }\end{array}$ & $\begin{array}{l}\text { Krytycyzm i ograniczo- } \\
\text { ne zaufanie }\end{array}$ & $\begin{array}{l}\text { Niewiarygodność i nie- } \\
\text { ufność }\end{array}$ \\
\hline $\begin{array}{l}\text { Postawa wobec osób spra- } \\
\text { wujących władzę }\end{array}$ & Szacunek & Niechęć & Nieufność i pogarda \\
\hline $\begin{array}{l}\text { Nadzieje łączone z ist- } \\
\text { niejącym porządkiem }\end{array}$ & $\begin{array}{l}\text { Nadzieje są } \\
\text { wysokie }\end{array}$ & Nadzieje są niskie & $\begin{array}{l}\text { Brak nadziei związanych } \\
\text { z istniejącym porządkiem }\end{array}$ \\
\hline
\end{tabular}

Źródło: W. Lamentowicz, za: W. Sokół, Legitymizacja systemów politycznych, Lublin 1997, s. 42 .

\section{Przejawy legitymizacji systemu demokratycznego w ustabilizowanych demokracjach}

Zastanawiać się można, czy to, co obserwujemy w Polsce, jest czymś wyjątkowym wśród innych społeczeństw demokratycznych.

Poziom zadowolenia $\mathrm{z}$ funkcjonowania demokracji utrzymuje się na względnie stałym poziomie - we Francji, Niemczech, Włoszech oraz krajach Beneluksu poziom zadowolenia z demokracji pomiędzy 1975 a $1995 \mathrm{r}$. oscylował wokół 2,5 punktów na czterostopniowej skali, gdzie 0 oznaczało całkowity brak, a 4 pełną satysfakcję. Zawarte w tabeli 2 dane pokazuja jeszcze wyższy poziom poparcia dla demokracji. Jak wskazuje T. Szawiel, „,na przełomie XX i XXI wieku przywiązanie do demokratycznych wartości w krajach liberalnych demokracji jest wyższe niż kiedykolwiek" (Szawiel, 2008). Wyraźne zaś rozczarowanie możliwościami uczestnictwa w demokracji, politykami czy rezultatami ich działań, nie przeniosło się na stosunek do demokracji.

Jednakże daje się zauważyć zniechęcenie obywateli samą ideą demokracji przedstawicielskiej (Norris, 2004; Klingemann, Fuchs, 1995). 
Tabela 2

Poparcie dla demokracji w wybranych krajach świata (w \%)

\begin{tabular}{||c|c|c||}
\hline \multicolumn{1}{|c|}{ Naród } & $\begin{array}{c}\text { Poparcie dla } \\
\text { idei demokracji }\end{array}$ & $\begin{array}{c}\text { Demokracja jako } \\
\text { najlepsza forma rządu }\end{array}$ \\
\hline Norwegia* & - & 93 \\
\hline Szwecja* & - & 93 \\
\hline Dania & 98 & 93 \\
\hline Grecja & 99 & 92 \\
\hline Szwajcaria* & - & 91 \\
\hline USA* & - & 88 \\
\hline Japonia* & - & 88 \\
\hline Holandia & 98 & 85 \\
\hline Portugalia & 99 & 84 \\
\hline Luksemburg & 98 & 83 \\
\hline Australia* & - & 83 \\
\hline Niemcy & 96 & 82 \\
\hline Hiszpania & 96 & 78 \\
\hline Francja & 95 & 78 \\
\hline Wielka Brytania & 93 & 76 \\
\hline Finlandia* & - & 75 \\
\hline Włochy & 93 & 74 \\
\hline Irlandia Północna & 95 & 65 \\
\hline Irlandia & 93 & 65 \\
\hline
\end{tabular}

Źródło: Eurobarometer 31a (1989); 1994-7 World Values Survey, za:

P. Norris, Critic citizens, Oxford 1999.

Kolejna ważna kwestia związana z legitymizacją systemu i jej przejawami na poziomie obywateli, to zachowania.

Jeśli chodzi o poziom frekwencji wyborczej, do początku lat 90. utrzymywała się ona na poziomie $73 \%$, od tego momentu średnia frekwencja to $64 \%$. Także poziom członkostwa w partiach politycznych w ustabilizowanych demokracjach spadał. W latach 1999-2001 wynosił on 19\% w Islandii, $12 \% \mathrm{w}$ Austrii i 2,6\% w Wielkiej Brytanii (dla porównania w Polsce było to 0,9\%) (Scarrow, 2010). Ogólnie spada poziom konwen-

4 Por. dane zamieszczone na stronie http://www.idea.int/vt/index.cfm (15.10.2013), a także A. Szostkiewicz, Frekwencja wyborcza. Mus nie dla nas, „Polityka”, 9 października 2007. 
cjonalnej aktywności politycznej, w której obywatele próbują wpłynąć na politykę za pośrednictwem instytucji przewidzianych przez prawo. Pippa Norris wskazuje, że spadająca aktywność polityczna obywateli, rodzi u wielu badaczy zaniepokojenie. Jeśli nawet nie o samą demokrację, to o legitymizację rządów reprezentatywnych (Norris, 2002).

Zupełnie inaczej wygląda zainteresowanie obywateli niekonwencjonalnymi formami aktywności politycznej, dającymi możliwość bezpośredniego oddziaływania obywateli na sferę polityczną. W tym zakresie widać zdecydowany wzrost poparcia dla tego typu aktywności oraz wzrost uczestnictwa w aktywnościach typu niekonwencjonalnego. Co charakterystyczne, większe zainteresowanie tą aktywnością występuje w bardziej ustabilizowanych demokracjach. Jak widać w zamieszczonej poniżej tabeli, poziom niekonwencjonalnej aktywności politycznej w zasadzie w każdym przypadku jest wyższy w krajach Europy Zachodniej i rozwiniętych krajach spoza Europy niż w krajach Europy Środkowo-Wschodniej i mniej rozwiniętych krajach południowych. Tendencja ta jest najbardziej wyraźna w przypadku bardziej spokojnych rodzajów tejże aktywności, jak petycje czy legalne demonstracje, ale widoczna jest nawet w formach najbardziej ekstremalnych. Początek tego typu aktywności w zachodnich demokracjach to połowa lat 50 . i protesty związane z ruchem praw obywatelskich w USA i Kampanią pro-rozbrojeniową w Europie Zachodniej. W naszej części Europy z kolei to koniec lat 80. i okres tzw. jesieni narodów. O ile w ustabilizowanych demokracjach wciąż wzrasta zainteresowanie bezpośrednim uczestnictwem w polityce, to w Europie Środkowo-Wschodniej, po okresie zwiększonego zainteresowania przed i w trakcie przechodzenia do demokracji, nastapiło odejście od tej formy aktywności (nazwane to zostało przez R. Ingleharta efektem post-honeymoon) (Inglehart, Catterberg, 2002).

Tabela 3

Udzial w niekonwencjonalnych formach aktywności politycznej w różnych regionach świata $(\mathrm{w} \%)$

\begin{tabular}{||c|c|c|c|c|c||}
\hline \multicolumn{1}{|c|}{ Region } & Petycja & $\begin{array}{c}\text { Legalna } \\
\text { demon- } \\
\text { stracja }\end{array}$ & Bojkot & Strajk & $\begin{array}{c}\text { Okupowa- } \\
\text { nie } \\
\text { budynku }\end{array}$ \\
\hline 1 & 2 & 3 & 4 & 5 & 6 \\
\hline Kraje zachodnioeuropejskie* & 56,0 & 27,3 & 13,4 & 6,9 & 4,5 \\
\hline $\begin{array}{l}\text { Rozwinięte kraje spoza Euro- } \\
\text { py** }\end{array}$ & 61,8 & 20,2 & 14,5 & 6,5 & 2,1 \\
\hline
\end{tabular}




\begin{tabular}{||l|c|c|c|c|c||}
\hline \multicolumn{1}{|c|}{1} & 2 & 3 & 4 & 5 & 6 \\
\hline $\begin{array}{l}\text { Kraje Europy } \\
\text { Srodkowo-Wschodniej*** }\end{array}$ & 29,3 & 15,0 & 4,9 & 3,4 & 1,1 \\
\hline $\begin{array}{l}\text { Mniej rozwinięte kraje } \\
\text { południowe**** }\end{array}$ & 16,3 & 12,7 & 8,0 & 5,2 & 3,5 \\
\hline
\end{tabular}

* Austria, Belgia, Dania, Finlandia, Francja, Niemcy, Wielka Brytania, Grecja, Islandia, Irlandia, Włochy, Luksemburg, Holandia, Portugalia, Hiszpania, Szwecja.

** Kanada, Izrael, Japonia, Republika Korei, Stany Zjednoczone.

*** Republika Czeska, Estonia, Wegry, Polska, Słowacja, Słowenia, Federacja Rosyjska, Ukraina. **** Argentyna, Indie, Indonezja, Meksyk, Pakistan, Filipiny, Południowa Afryka, Uganda.

Źródło: World Values Survey 1999-2002, za: D. Rucht, Rosnqce znaczenie polityki protestu, w: Zachowania polityczne 2, red. R. J. Dalton, H. D. Klingemann, Warszawa 2010, s. 357.

Z kolei dane zawarte $\mathrm{w}$ tabeli 4 pozwalają prześledzić zmiany w poziomie aktywności niekonwencjonalnej pomiędzy połową lat 70 . a połową lat 90. Jak widać, w Wielkiej Brytanii, Niemczech Zachodnich, Holandii, Austrii, USA, Włoszech, Szwajcarii i Finlandii w analizowanym okresie zwiększył się udział obywateli w zakresie wszystkich aktywności typu protest, choć najwyraźniejszy był ten wzrost w odniesieniu do bardziej spokojnych form, takich jak podpisywanie petycji czy udział w demonstracji.

Tabela 4

Zmiany w zakresie aktywności typu protest pomiędzy połową lat 70. a połową lat 90 .

\begin{tabular}{||l|c|c|c|c||}
\hline \multicolumn{1}{|c|}{ Rodzaj aktywności } & Polowa lat 70. & Wczesne 1980 & $\mathbf{1 9 9 0}$ & Polowa lat 90. \\
\hline Podpisanie petycji & 34 & 46 & 54 & 60 \\
\hline Demonstracje & 9 & 14 & 18 & 17 \\
\hline Bojkoty konsumenckie & 5 & 8 & 11 & 15 \\
\hline Nielegalne strajki & 2 & 3 & 4 & 4 \\
\hline Okupowanie budynków & 1 & 2 & 2 & 2 \\
\hline
\end{tabular}

Źródło: (Norris, 2002).

Warto również sprawdzić, jak wyglądało zainteresowanie tymi aktywnościami w krajach prezentujących różny poziom zaawansowania rozwoju demokracji. Na podstawie przedstawionych tam danych, można wysnuć wniosek, iż niemal w każdym przypadku wyższy poziom aktywności politycznej obserwuje się w krajach bardziej zdemokratyzowanych. Najbardziej jest to widoczne w przypadku podpisywania petycji (60,7\% wskazań w starych demokracjach i tylko $10 \%$ w krajach niedemokratycznych) oraz bojkotu - odpowiednio 17\% i 3\% wskazań. 
Tabela 5

Porównanie poziomu aktywności politycznej ze względu na zaawansowanie procesów demokratycznych $\mathbf{w}$ połowie lat 90.

\begin{tabular}{||l|c|c|c|c|}
\hline $\begin{array}{c}\text { Procent osób, które podjęly daną } \\
\text { aktywność }\end{array}$ & $\begin{array}{c}\text { Stare de- } \\
\text { mokracje }\end{array}$ & $\begin{array}{c}\text { Nowe de- } \\
\text { mokracje }\end{array}$ & $\begin{array}{c}\text { Semi-de- } \\
\text { mokracje }\end{array}$ & $\begin{array}{c}\text { Nie-demo- } \\
\text { kracje }\end{array}$ \\
\hline Dyskusje polityczne & 72,3 & 72,2 & 68,2 & 65,6 \\
\hline Głosowanie & 73,1 & 68,9 & 56,3 & 60,8 \\
\hline Aktywność obywatelska & 73,0 & 60,3 & 63,1 & 40,7 \\
\hline Podpisywanie petycji & 60,7 & 22,3 & 19,4 & 10,0 \\
\hline Udział w demonstracji & 19,1 & 12,5 & 15,7 & 19,1 \\
\hline Bojkot & 17,1 & 6,7 & 7,5 & 3,0 \\
\hline Przyłączenie się do nielegalnego strajku & 8,2 & 5,0 & 4,7 & 3,5 \\
\hline $\begin{array}{l}\text { Aktywne członkostwo w związku za- } \\
\text { wodowym }\end{array}$ & 4,8 & 4,4 & 5,6 & 5,2 \\
\hline Aktywne członkostwo w partii & 5,8 & 4,2 & 4,7 & 2,5 \\
\hline Okupacja budynku & 1,5 & 2,0 & 1,6 & 0,3 \\
\hline
\end{tabular}

Źródlo: (Norris, 2002, s. 14).

Jeśli chodzi o zaufanie do polityków i instytucji politycznych, od lat 70. nastapił dramatyczny spadek wskaźników praktycznie we wszystkich krajach tzw. stabilnych demokracji. Poczucie, że ,polityków obchodzi, co myślą obywatele", miało w 1965 r. 80\% Amerykanów i ok. 50\% Szwedów, zaś w 1995 r. zaledwie 25\% Amerykanów i 30\% Szwedów. W USA bardzo wyraźnie spadł też poziom zaufania do polityków (wszystkie dane za: Dalton, 2004). Spada również poziom identyfikacji partyjnej. Zaczynając od Stanów Zjednoczonych i Kanady, a kończąc na Austrii i Niemczech, partie polityczne znajdują się na szarym końcu listy instytucji cieszących się zaufaniem obywateli. Dramatycznie spada również zaufanie do demokratycznych instytucji - w 1985 r. 48\% Brytyjczyków darzyło swój parlament zaufaniem, 20 lat później było ich tylko 25\%. Podobnie w Szwecji - pomiędzy 1986 a 1996 r. zaufanie do Riksdagu spadło z 51\% do 19\% (Dalton, 2004).

\section{Zmiana formy aktywności politycznej zagrożeniem dla legitymizacji demokracji?}

W kontekście przedstawionych powyżej danych, rodzi się pytanie o to, czy zmiana w zakresie form aktywności politycznej obywateli stanowi za- 
grożenie dla legitymizacji systemu demokratycznego. Jeśli chodzi o kraje ustabilizowanych demokracji, wydaje się, że takiego problemu nie ma. Jak wykazują badania, w aktywnościach typu niekonwencjonalnego biora udział przedstawiciele niemal wszystkich warstw społecznych. Dodatkowo we wszystkich wyróżnionych w analizach regionach zauważalna jest tendencja: ,im wyższy poziom wykształcenia, tym wyższy procent osób aktywnych" (Rucht, 2010, s. 359). Być może jest to raczej wyraz zmiany oczekiwań w stosunku do demokracji, tego że demokracja przedstawicielska nie spełnia już oczekiwań obywateli (Ranciere, 2008; Marczewsko-Rytko, 2001; Rosanvallon, 2011; Mouffe, 2005).

A czy spadająca frekwencja stanowi zagrożenie dla procesu legitymizacji systemu demokratycznego?

Według analiz prowadzonych przez M. Cześnika w Polsce, istnieje korelacja pomiędzy uczestnictwem w wyborach a zadowoleniem $\mathrm{z}$ funkcjonowania demokracji. O ile spośród osób zdecydowanie zadowolonych $\mathrm{z}$ demokracji ponad $72 \%$ brało udział w wyborach, o tyle spośród niezadowolonych, udział zadeklarowało 55\% (por. tabela 6).

Tabela 6

\begin{tabular}{||l|c|c||}
\hline \multirow{2}{*}{$\begin{array}{c}\text { Zadowolenie z funkcjonowania } \\
\text { demokracji w Polsce }\end{array}$} & \multicolumn{2}{|c|}{ Udzial w wyborach parlamentarnych 2001 r. } \\
\cline { 2 - 3 } & Tak & Nie \\
\hline Zdecydowanie zadowolony & $72,2 \%$ & $27,5 \%$ \\
\hline Raczej zadowolony & $65,7 \%$ & $34,3 \%$ \\
\hline Raczej niezadowolony & $56,1 \%$ & $43,9 \%$ \\
\hline Zdecydowanie niezadowolony & $48,0 \%$ & $52,0 \%$ \\
\hline Chi kwadrat Pearsona & Wartość & Stopnie swobody \\
\cline { 2 - 3 } & 27,227 & 4 \\
\hline
\end{tabular}

Źródlo: (Cześnik, 2004).

Oczywiście aspekt legitymizacyjny wyborów nie we wszystkich demokracjach jest jednakowo istotny - w niektórych krajach znacznie ważniejsze są pozostałe funkcje, które wybory mogą pełnić w systemie politycznym. Jak pisze M. Cześnik, „Wydaje się jednak prawie pewne, że aspekt legitymizacyjny powinien być szczególnie istotny w krajach przechodzących przeobrażenia, dopiero się demokratyzujących lub konsolidujących porządek demokratyczny. Ponieważ procedury demokratyczne nie są tam jeszcze zakorzenione, legitymizacyjny aspekt wyborów - i udziału w nich szerokich rzesz społeczeństwa - musi być w takich krajach wy- 
jątkowo ważny. Jeśli się uzna, że wybory w danym systemie służą przede wszystkim uprawomocnieniu władzy, to poziom uczestnictwa wyborczego można traktować jako funkcję stosunku obywateli do demokracji" (Cześnik, 2009; Raciborski, 2005, s. 28-29). Przedstawione powyżej wyniki badania wydają się to potwierdzać. Do innych nieco wniosków doszli w swych analizach C. McManus-Czubinska i W. L. Miller. Ich zdaniem niska frekwencja wyborcza w Polsce ani nie jest zagrożeniem dla legitymizacji systemu demokratycznego (gdyż osoby trwale niegłosujące nie są przeciwnikami systemu, raczej są apatyczne, bierne i niepoinformowane), ani nie prowadzi do niereprezentatywnego rządu. Sama zaś frekwencja może obniżać legitymizację, ale „tylko wówczas, gdy wybory zamieniają się w plebiscyt popularności reżimu, gdy system sam z siebie stawia sobie za cel uzyskanie wysokiej frekwencji i nie jest w stanie tego osiagnąć, gdyż lepiej lub gorzej zorganizowana opozycja nawołuje do absencji" (McManus-Czubinska, Miller, 2004, s. 272-273).

Warto również sprawdzić, jak wygląda poziom legitymizacji demokracji w Europie. Poziom legitymizacji systemu mierzony był w European Values Study za pomocą odpowiedzi na trzy pytania: „Ogólnie rzecz biorąc, na ile jest P. zadowolony(a) z obecnego stanu gospodarki (swojego kraju)?”, „Jeżeli chodzi o rząd, na ile jest P. zadowolony(a) ze sposobu jego działania?”, „A ogólnie rzecz biorąc, na ile jest P. zadowolony(a) z funkcjonowania demokracji w (nazwa kraju respondenta)?". Respondent mógł się ustosunkować do tych pytań na 11-punktowej skali, gdzie 0 oznaczało zupełnie niezadowolony, a 11 zupełnie zadowolony. Według danych z roku 2006 najwyższy poziom legitymizacji występował w krajach skandynawskich oraz Holandii, Irlandii i Szwajcarii. Najniżej zaś lokują się państwa Europy Środkowo-Wschodniej, zwłaszcza Ukraina, Bułgaria i Węgry (Domański, Słomczyński, 2011, s. 75). Widać więc, że wysoki poziom aktywności niekonwencjonalnej występuje w krajach charakteryzujących się również wysokim poziomem legitymizacji. Słuszna wydaje się w tym kontekście konstatacja Fuchsa i Klingemanna komentujących opisywane tu przemiany, że współczesne demokracje będą w stanie sprostać wyzwaniom (zwiększeniu aktywności niekonwencjonalnej, spadkowi zaufania do polityki i polityków), przed którymi stanęły.

Warto w tym kontekście wskazać koncepcję kontrdemokracji sformułowaną przez Pierre’a Rosanvallona. Idealnie tłumaczy ona przemiany przedstawione $\mathrm{w}$ artykule $\mathrm{w}$ zakresie aktywności politycznej, ale także postaw obywateli wobec współczesnych systemów demokratycznych. 
Nieufność demokratyczna (charakteryzująca współczesnych krytycznych obywateli) (Norris, 1999) wyraża się jego zdaniem w trzech trybach: władzy nadzorowania, różnych postaciach piętrzenia przeszkód oraz stawianiu przed sądem. Sama nieufność demokratyczna polega na czuwaniu, by „wybrana władza dotrzymywała swoich zobowiązań i znajdowanie środków, by utrzymać pierwotne wymogi co do służby na rzecz wspólnego dobra" (Rosanvallon, 2011).

I tak, władza nadzoru oznacza czujność, powiadamianie i ocenianie. Czujność opisuje ciągłą gotowość do działania pomiędzy wyborami, która czyni z obywateli-ludu „drzemiącego olbrzyma”. Powiadamianie odnosi się do ujawniania skandali i afer, w które zamieszani są politycy. Ostatni element, czyli ocenianie polega na „udokumentowanej, technicznie uzasadnianej, a czasem ujmowanej ilościowo ocenie pojedynczych działań lub szerzej rozumianej polityki" (Rosanvallon, 2011).

Stawianie przeszkód z kolei nazywane jest również suwerennością krytyczną, ponieważ przejawia się w różnorodnych działaniach typu protest, związanych ze wspomnianą już aktywnością niekonwencjonalną.

Trzeci element składający się na władzę nadzoru, najmniej nas interesujący, oznacza stawianie polityków przed sądem, również w sensie dosłownym.

Autor koncepcji kontrdemokracji przedstawia również propozycję swoistego remedium na zniechęcenie współczesnych obywateli obowiązującym wzorem demokracji. Proponuje on tzw. nowoczesny system mieszany, na który składają się:

- rząd elektoralno-przedstawicielski (instytucjonalne osadzenie),

- kontrdemokracja (kontestacyjna żywotność),

- refleksyjno-deliberatywna praca polityczności nadająca historyczną i społeczną ciagłość (Rosanvallon, 2011, s. 220).

$\mathrm{Na}$ temat zniechęcenia liberalnym wzorem demokracji pisze również Chantal Mouffe, jako remedium dla niej wskazuje model deliberatywnej demokracji (Mouffe, 2005). Wydaje się jednak, że w warunkach polskich idea demokracji partycypacyjnej, jak również deliberatywnej nie znajdzie szerszego poparcia. Potwierdzają to badania prowadzone przez A. Zielińską w ramach Civic Education Study w latach 1996-1998 oraz 2000. Polską młodzież wyróżniała od młodych z innych krajów wyraźna niechęć wobec niekonwencjonalnych form aktywności politycznej, częściej odrzucali działania kontestacyjne i obywatelskie nieposłuszeństwo (Zielińska, 2008). Badana młodzież z Polski za obowiązki dobrego obywatela uważała przestrzeganie prawa i udział w wyborach (Zielińska, 2004; 
Pająk, 2007). Obserwowane w ostatnim czasie działania, np. w sprawie $\mathrm{ACTA}^{5}$, mogą oczywiście świadczyć o przemianach zachodzących w sferze świadomości Polaków. O tym, iż władza nadzorowania, o której pisał Rosenvallon, zaczyna odgrywać ważniejszą rolę, niż władza kartki wyborczej. Brak jednak jest jak na razie badań, które mogłyby nam pomóc odpowiedzieć na pytanie, czy jest to trwała tendencja (Raciborski, 2011).

Zgodzić się też należy z konstatacją P. Rosanvallona, że współczesna radykalność przestała łączyć się z perspektywą rewolucyjnych zamieszek - „Obecnie jawi się pod postacią niewzruszonego głosu moralnego, który bezwzględnie stygmatyzuje sprawujących władzę i nieustannie mobilizuje tych, co zaspali. Radykalizm przeobraził się w codzienny palec oskarżyciela, w nóż stale jątrzący rany świata. Nie jest już natomiast armatą i nie oblega fortec władzy, szykując się do decydującej batalii” (Rosanvallon, 2011). Pamiętać jednak należy, że wniosek taki uprawniony jest w odniesieniu do tych demokracji, które nazwać można ustabilizowanymi. W krajach obszaru Europy Środkowo-Wschodniej zwiększona aktywność typu niekonwencjonalnego może prowadzić do poważnych konsekwencji, o czym przekonuje przykład Ukrainy, ale także bardziej zaawansowanych w procesie demokratyzacji Węgier.

\section{Bibliografia}

Blais A. (2010), Frekwencja wyborcza, w: Zachowania polityczne 2, red. R. J. Dalton, H. D. Klingemann, PWN, Warszawa.

Cześnik M. (2004), Uczestnictwo wyborcze, stosunek do demokracji, legitymizacja władzy. Przypadek Polski, w: Populizm a demokracja, red. R. Markowski, Wydawnictwo ISP PAN, Warszawa.

Cześnik M. (2006), Voter Turnout and Democratic Legitimacy in Central Eastern Europe, „Polish Sociological Review”, nr 4/156.

Cześnik M. (2008), Partycypacja wyborcza Polaków, Wydawnictwo ISP, Warszawa.

Cześnik M., Grzelak P., Kotnarowski M. (2010), Niestabilność uczestnictwa wyborczego w Polsce, w: Niestabilność wyborcza w Polsce, red. M. Cześnik, Wydawnictwo ISP, Warszawa.

Dalton R. (2004), Democratic challenges, democratic choices, Oxford University Press, Oxford.

${ }^{5}$ Według analiz J. Zająca i D. Batorskiego wśród protestujących dominowały osoby poniżej 24. roku życia, za: Kto protestuje przeciw ACTA - profil wedtug badaczy, http://www.rp.pl/artykul/801796.html, 15.10.2013. 
Domański H., Słomczyński K. M. (2011), Pozycja społeczna a poparcie dla systemu społeczno-ekonomicznego, w: Legitymizacja w Polsce. Nieustajacy kryzys w zmieniajacych się warunkach, red. A. Rychard, H. Domański, Wydawnictwo IFiS PAN, Warszawa.

Inglehart R., Catterberg G. (2002), Trends in Political Action: The Developmental Trend and the Post-Honeymoon Decline, www.worldvaluessurvey.org/wvs/ articles/folder_published/publication_514.

Kalinowska B. (2009), Stosunek Polaków do Polityki i polityków w świetle sondaży i badań własnych, w: Polityka i politycy. Diagnozy - oceny - doświadczenia, red. J. Miluska, Poznań.

Klingemann H. D., Fuchs D. (red.) (1995), Citizens and the state, Oxford University Press, Oxford.

Komunikat z badań CBOS, Nadal nieprzekonani-Polacy o podwyższeniu wieku emerytalnego, kwiecień 2012.

Komunikat z badań CBOS, Nastroje społeczne w maju, maj 2012.

Komunikat z badań CBOS, Oceny instytucji publicznych, wrzesień 2014.

Komunikat z badań CBOS, Oceny wybranych instytucji publicznych, maj 2012.

Komunikat z badań CBOS, Opinia publiczna o Acta, marzec 2012.

Komunikat z badań CBOS, Opinie o demokracji, październik 2011.

Komunikat z badań CBOS, Opinie o demokracji, wrzesień 2014.

Komunikat z badań CBOS, Polacy o demokracji, wrzesień 2013.

Komunikat z badań CBOS, Postawy wobec demokracji, jej rozumienie i oceny, maj 2010.

Komunikat z badań CBOS, Stosunek do demokracji i jego praktyczne konsekwencje, lipiec 2014.

Komunikat z badań CBOS, Stosunek do instytucji państwa oraz partii politycznych po 25 latach, luty 2014.

Kostadiova T. (2003), Voter turnout dynamics in post-Communist Europe, „European Journal of Political Research", nr 42.

Krzemiński A. (2011), Wkurzeni, „Polityka”, nr 7 z 12 lutego.

Linz J. J. (1998), Kryzys, załamanie i powrót do równowagi, w: Władza i społeczeństwo 2, red. J. Szczupaczyński, Wydawnictwo Naukowe Scholar, Warszawa.

Marczewska-Rytko M. (2001), Demokracja bezpośrednia w teorii i praktyce, Wydawnictwo UMCS, Lublin.

Marti U. (2010), Niedotrzymana obietnica demokracji, Instytut Wydawniczy Książka i Prasa, Warszawa.

McManus-Czubinska C., Miller W. L. (2004), Kiedy frekwencja wyborcza ma znaczenie, w: Populizm a demokracja, red. R. Markowski, Wydawnictwo ISP PAN, Warszawa.

Mouffe Ch. (2005), Paradoks demokracji, Wydawnictwo Naukowe Dolnośląskiej Szkoły Wyższej Edukacji TWP, Wrocław. 
Norris P. (1999), Introduction. The growth of critical citizens, w: P. Norris, Critical Citizens: Global Support for Democratic Government, Oxford University Press, Oxford.

Norris P. (2002), Democratic Phoenix. Agencies, Repertoires, \& Targets of Political Activism, wystapienie zaprezentowane na konferencji organizowanej przez Amerykańskie Stowarzyszenie Psychologii Politycznej, Boston 29 VIII-1 IX 2002.

Norris P. (2004), Critical citizens, Oxford University Press, Oxford.

Pająk B. (2007), Koncepcje obywatelstwa wedtug młodych Polaków, w: Odmiany myślenia o społeczeństwie obywatelskim, red. L. Kacprzak, D. Mierzejewski, Wydawnictwo PWSZ w Pile, Piła.

Pająk B. (2008), Demokracja polska i niemiecka. Tradycja, teraźniejszość, perspektywy, Wydawnictwo WNPiD, Poznań.

Raciborski J. (2011), Obywatelstwo w perspektywie socjologicznej, PWN, Warszawa.

Ranciere J. (2008), Nienawiść do demokracji, Instytut Wydawniczy Książka i Prasa, Warszawa.

Rosanvallon P. (2011), Kontrdemokracja. Polityka $w$ dobie nieufności, Wydawnictwo Naukowe Dolnośląskiej Szkoły Wyższej Edukacji TWP, Wrocław.

Rucht D. (2010), Rosnace znaczenie polityki protestu, w: Zachowania polityczne 2, red. R. J. Dalton, H. D. Klingemann, PWN, Warszawa.

Scarrow S. E. (2010), Aktywność polityczna i członkostwo partyjne, w: Zachowania polityczne 2, red. R. Dalton, H. D. Klingemann, PWN, Warszawa.

Skarżyńska K. (2005), Człowiek a polityka. Zarys Psychologii politycznej, GWP, Gdańsk.

Sobkowiak L. (2000), Delegitymizacja polityczna, w: Studia z teorii Polityki, t. III, Wydawnictwo Uniwersytetu Wrocławskiego, Wrocław.

Sokół W. (1997), Legitymizacja systemów politycznych, Wydawnictwo UMCS, Lublin.

Szawiel T. (2008), Kryzys demokracji a poparcie systemu demokratycznego w Polsce, w: Populizm a demokracja, red. R. Markowski, Wydawnictwo ISP PAN, Warszawa.

Szostkiewicz A. (2007), Frekwencja wyborcza. Mus nie dla nas, „Polityka”, 9 października.

Zielińska A. (2004), Koncepcje obywatelstwa i planowana przez nastolatków aktywność w sferze publicznej, w: Młodzi obywatele. Wyniki międzynarodowych badań młodzieży, red. R. Dolata, K. Koseła, A. Wiłkomirska, A. Zielińska, Wydawnictwo Uniwersytetu Warszawskiego, Warszawa.

Zielińska A. (2008), Nastoletni uczniowie o demokracji. Uwarunkowania społeczno-demograficzne i edukacyjne pogladów młodzieży, Wydawnictwo Uniwersytetu Warszawskiego, Warszawa. 
The Premises for the Stability of Democracy - the Legitimization of the System on the Level of the Individual

\begin{abstract}
Summary
The purpose of the paper is to present the legitimization process of the democratic system at the level of individual citizens - their attitudes and behavior - in the context of the transformations that are occurring in more advanced democracies than Poland. The starting point is provided by the theory of J. J. Linz, who points to the dependence between the stability of the system and legitimization. Next, numerous studies are discussed concerning the symptoms of system legitimization on the individual level in Poland and Western European countries. A hypothesis of the dependence between the transformation of political activities (including increasing unconventional activities) and the degree of legitimization of the system is also tested.
\end{abstract}

Key words: legitimization, political activities, democracy, attitude towards democracy, stability of democracy 
